Ивана Антонић

(Одсек за српски језик и лингвистику Филозофски факултет, Универзитет у Новом Саду)
Прегледни рад

УДК 050.488(497.113 Novi Sad)PRILOZI PROUČAVANJU JEZIKA"1965/2019"

DOI 10.19090/ppj.2019.50.5-19

\title{
ПОВОДОМ ПЕДЕСЕТОГ БРОЈА ЧАСОПИСА ПРИЛОЗИ ПРОУЧАВАЫУ ЈЕЗИКА
}

Часопис Прилози проучавању језика покренула је Катедра за јужнословенске језике Филозофског факултета Универзитета у Новом Саду 1965. године. У првом броју, у уводном тексту под насловом Поводом овог почетка редакција часописа обратила се стручној јавности следећим речима: „Прилози проучавању језика покрећу се са циљем да се омогући објављивање радова трудбеника окупљених око Катедре за јужнословенске језике на Филозофском факултету Новосадског универзитета. Ту he се публиковати радови студената, семинарски, дипломски и магистарски, уколико материјал или идеје у њима могу бити од користи за језичку науку, а такође и радови људи који су запослени на другим местима, махом у средњим школама у Војводини, али који су, искрено заинтересовани за језичка питања, нашли времена и снаге да поред других дужности даду и прилоге истраживању те проблематике.” Редакција потом наглашава да ће члановима Катедре бити „задовољство да укажу помоћ људима који су пришли послу са толико истинске љубави”, али и да та помоћ „не сме прекорачити једну одређену границу”, те да ће „радови овде објављени бити реално сведочанство о могућностима које у овом [датом] тренутку имају њихови аутори којима су ово први кораци ка научном раду."

Од првога броја Прилози проучавању језика излазе као редовна периодична публикација - један број годишње, пред крај јесењег семестра, управо оном динамиком коју је прва његова редакција и планирала. Ипак, било је изузетака. Објављена су два двоброја - 13-14 за 1977-1978. годину и 28-29 за 1997-1998. годину, као и два троброја - 24-26 за 1988-1990. и 30-32 за 1999-2001. годину. Нажалост, између 1991. и 1995. године привремено је морало бити обустављено штампање часописа. Тако се догодило да 50. број излази као 33. књига у 54. години од оснивања. Разлози обједињавања два / три броја били су претежно финансијске природе, а прекид у објављивању 
настао је у периоду државног и финансијског краха у првој половини деведесетих година. Ако се изузму повремене потешкоће, финансирање часописа углавном је за протеклих пола века било стабилно и подржано од надлжених покрајинских институција: Комисије за научни рад АПВ, 1965, односно свих каснијих покрајинских служби надлежних за научноистраживачки рад, а и сама Катедра је, по потреби, из сопствених извора, суфинансирала штампање часописа.

Издавач часописа Прилози проучавању језика није се мењао. Мењао се само назив организационе јединице Филозофског факултета која је била издавач под утицајем промена у организационој структури самога факултета и правно-финансијској самосталности организационих јединица. Тако ће у импресуму од 1-12. броја (1965-1976) као идавач словити Катедра за јужнословенске језике, од двоброја 13-14 до троброја 24-26 (1977-1990), то ће бити Институт за јужнословенске језике. У импресуму броја 27 и двоброја 28-29 (1996-1998) стоји Одсек за српски језик и лингвистику, на троброју 3032 (1999-2001) Катедра за српски језик и лингвистику, а од броја 33 до 49 (2002-2018), укључујући и овај 50. број за 2019. поново Одсек за српски језик и лингвистику.

Оснивачку редакцију чинили су професори Павле Ивић, Рудолф Коларич и Александар Младеновић и они су приредили прва четири броја (19651968). Од броја 5-7 (1969-1971) редакцију чине Павле Ивић, Александар Младеновић и Јован Кашић, ${ }^{1}$ а од броја 8-12 (1972-1976) њима се придружује и Драгољуб Петровић. Од двоброја 13-14 до 18 (1977-78-1982) Павла Ивића у редакцији замењује Милка Ивић. Од броја 19-21 (1983-1985) редакцију чине Вера Јерковић, Јован Јерковић, Александар Младеновић, Драгољуб Петровић и Свенка Савић, а у броју 22 (1986) Драгољуба Петровића замењује Јован Кашић, да би у редакцији броја 23-24-26 (19871988-1990) на место преминулог Јована Кашића поново дошао Драгуљуб Петровић, а у њу се укључио и Мато Пижурица. Након петогодишње паузе у излажењу, број 27 (1996) приредила је редакција у саставу Вера Јерковић, Милорад Радовановић, Драгољуб Петровић, Мато Пижурица и Свенка Савић, а двоброј 28-29 (1997-98) Ивана Антонић, Јасмина Грковић Мејџор,

\footnotetext{
${ }^{1}$ Навођење имена чланова редакције у импресуму углавном је било по азбучном реду, али и по звању или годинама старости.
} 
Драгољуб Петровић, Мато Пижурица и Милорад Радовановић. Од троброја 30-32-42 (1999-2001-2011) редакцију чине Мато Пижурица, Јасмина Грковић Мејџор, Вера Васић, Љиљана Суботић, Владислава Петровић/Ружић и Ивана Антонић, а од броја 43-47 (2012-2016) професора Пижурицу замењује Жарко Бошњаковић, а редакцији се придружују и Нада Арсенијевић, Душанка Звекић Душановић и Жељко Марковић. Коначно, у последња два броја 48-49 (2017-2018) редакција се знатно проширује и подмлађује, па се постојећем саставу прикључују и Милан Ајџановић, Марина Курешевић, Јасмина Дражић, Наташа Киш, Јелена Ајџановић, Јелена Редли и Данка Урошевић.

Одговорни [и главни] уредник од броја 1-12 (1965-1976) био је професор Павле Ивић, а од двоброја 13-14 до троброја 24-26 (1977-1978-1990) главни уредник је био професор Александар Младеновић. Од броја 20 (1984) раздвојена је улога главног и одговорног уредника. Улогу главног уредника наставља да обавља професор Младеновић, а улогу одговорног уредника преузима по службеној дужности шеф Одсека, па је у бројевима 20 и 21 (1984-1985) то професор Јован Јерковић, а у броју 22 (1986) професор Јован Кашић. Од броја 23-27 (1987-1996) одговорни уредник је Мато Пижурица. У броју 27 (1996), након одласка професора Младеновића у пензију, главни уредник постаје професор Драгољуб Петровић. Од двоброја 28-29 (19971998) поново је обједињена улога главног и одговорног уредника, и од тада обе функције обавља шеф Одсека по службеној дужности. У двоброју 28-29 (1997-1998) то је био Драгољуб Петровић. Од троброја 30-32-37 (1999-20012006) улогу главног и одговорног уредника преузима Љиљана Суботић, од броја 38-42 (2007-2011) ту дужност обавља Јасмина Грковић Мејџор, а бројеве 42-48 (2012-2017) уредила је Владислава Ружић. Од броја 49 (2018) Прилоге проучавању језика уређује Душанка Звекић Душановић.

Дужност секретара редакције најдуже су обављали професори Александар Младеновић, бројеви 1-12 (1965-1976), и Драгољуб Петровић, 13-14-21 (1977-1978-1985). У броју 22 (1986) изостало је име секретара редакције. Од броја 23-27 (1987-1996) секретар редакције била је Свенка Савић, а у двоброју 28-29 (1997-1998) Ивана Антонић. Од троброја 30-32-35 (1999-2001-2004) ту дужност обављала је Марина Петровски/Курешевић, од броја 36-42 (2005-2011) Миливој Алановић, а од броја 43-48 (2012-2017) Гордана Штрбац. Од броја 49 (2018) секретар редакције јесте Јелена Редли. 
Графичко решење насловне и библиографске стране, као и типографија назива часописа, нису се мењали. Графички изглед, ахроматски сиво-бели колорит и тонски контраст минимално су мењани под утицајем промена у технологији штампе, а видно од броја 27 (1996). До троброја 24-26 (19881990) графика штампаног текста била је класична, словослагачка, а од броја 27 (1996) она је ововремена, компјутерска. У ери класичне словослагачке штампе, од броја 1-24-26 (1965-1988-1990), за техничко уређивање часописа и завршну коректуру и лектуру помно се старао професор Младеновић, најпре као секретар редакције, а касније и као уредник. У бројевима од 1996. техничко уређивање једним делом је зависило од секретара и уредника, а касније и рецензената, односно њихове контроле усаглашености текста са техничким упутством, али ипак, једним делом, и од оних којима је препуштан прелом текста. То је, у бројевима од 27. до 49, довело до извесних неусаглашености у техничком уређењу. Пошто је часопис Прилози проучавању језика програмски био оријентисан ка младим истраживачима језика, студентима основних и последипломских студија, испод имена аутора и наслова на почетној страници текста, при десној маргини, курзивним словима, навођено је и име професора под чијим је руководством рад урађен. Тај простор је до броја 39 (2008) остајао празан само када је аутор, одбраном доктората, стекао статус самосталног истраживача или из одређених разлога није имао ментора, а редакција је проценила да рад има потребне квалитете за објављивање. Иако таква програмска оријентација часописа није никада промењена, од броја 40 (2009) испод наслова више се не наводи име професора који је руководио радом, а упућивање, у првој напомени, на порекло настанка рада и евентуалног ментора веома је неуједначено. Неки аутори су видно истицали име ментора, неки су наводили имена чланова комисије, ако се радило о дипломском (мастер) раду, неки су давали прецизне податке о степену студија и курсу професора на којем је рад, као семинарски, настао, или су наводили пројекат на којем је рад рађен, али ипак већина, када су радови рађени на курсу одређеног наставника на дипломским или докторским студијама, није наводила никакве податке. Такве податке, по правилу, нису наводили ни они аутори који нису били студенти или сарадници Одсека.

До броја 23 (1987) текстови објављивани у часопису Прилози проучавању језика, осим напомена, ређе табела и графикона, нису били опремљени ниједним другим пратећи елементом уобичајеним за данашњу опрему 
научног текста у периодици, што је било у потпуности у сагласности са тада владајућим принципима опреме таквог типа текста у стручним и научним часописима. Од троброја 24-26 (1988-1990) уводи се Резиме на страном језику на крају текста (у том броју сви резимеи су били на руском језику). Од броја 27 (1996) сваки рад добија УДК број и ознаку категорије: Научни рад [за бројеве 40-42 (2009 - 2011) и датум пријама рада], на првој страни, изнад наслова, у горњем десном углу, а испод наслова Сажетак и Кључне речи, и на самом крају Резиме на страном језику. Од броја 40 (2009), на самом крају књиге, испред таблице садржаја, штампа се Упутство ауторима за техничко уређење текста, а такође од броја 40 (2009), од када се више не наводи име професора под чијим руководством је рад рађен, у импресуму се дају имена рецензената који су учествовали у рецензирању радова у датом броју, а уз име аутора на почетку наводи се и афилијација, а на самом крају иза Резимеа име аутора, афилијација/приватна адреса и мејл адреса. Ипак, од броја 48 (2017) навођење афилијације испод имена аутора на почетку неуједначено је. Промене у опреми текстова и пратећој апаратури биле су усмерене ка усклађивању часописа са новијим кретањима у техничком уређивању научне периодике, али су биле подстакнуте и жељом редакције да се часопис нађе на листи категоризованих научних часописа. Након 2002. часопис је најпре неколико година био у категорији научних часописа изузетног националног значаја (Р61), а тренутно је на листи научних часописа националног значаја (M52). До ове промене је дошло само због тога што је часопис намењен првенствено почетницима и млађим истраживачима. Сви досадашњи бројеви изашли су у папирном издању (ISSN 0555-1137), а од броја 43 (2012) објављује се и електронско издање (ISSN 2334-7457) на адреси <http://ppj.ff.uns.ac.rs/index.php/ppj/issue/archive>. Дигитализација бројева од 1-42 (1965-2011) у току је и требало би да сви бројеви буду доступни у дигиталној форми до краја 2019. године. Од броја 35 (2004) Прилози проучавању језика добијају CIP - Каталогизација у публикацији Библиотека Матице српске, Нови Сад, број у бази Кобис (COBISS.SR-ID 42732295) и бар-код на задњим корицама, а од броја 36 (2005) и знак (лого) Филозофског факултета на предњим корицама.

У часопису Прилози проучавању језика текстове су објављивали домаћи аутори, али и понеки страни, на српскохрватском / српском језику, а штампано је и пет радова руских аутора на руском језику и један рад македонског аутора на македонском језику. Текстови на српскохрватском / 
српском језику штампани су у великој већини ћирилицом ( 80\%), у складу са типографијом назива самога часописа, али је било и текстова који су штампани латиницом ( 20\%). Закључно са бројем 49 (2018) објављено је 472 рада и 14 других прилога, дакле укупно 486 текстова, у просеку безмало 10 текстова по броју. Највише је текстова објављено у броју 4 (1968): 19 радова и један прилог, а најмање у бројевима 10 (1974), 11 (1975) и 47 (2016) по шест радова.

На страницама нашега часописа до 49. броја огласило се својим прилозима проучавању језика 282 аутора, а од укупног броја објављених текстова 15 прилога је урађено у коауторству два, и два прилога у коауторству три аутора. Сви остали текстови су ауторски. Најпре, међу ауторима који су своје прве прилоге језичкој науци објавили на овим страницама били су готово сви они који су касније постали сарадници и/или професори на Одсеку за српски језик и лингвистику (како они који су почели на Катедри за јужнословенске језике тако и они који су прво радили у Институту за лингвистику): Вера Јерковић ${ }^{2}$ и Јован Јерковић, Свенка Васиљев/Савић, Драгољуб Петровић, Велимир Михајловић, Гордана Вуковић, Милица Грковић, Мато Пижурица, Милорад Радовановић, Мирјана Јоцић, Југослава Арсовић, Љиљана Суботић, Владислава Петровић/Ружић, Жарко Бошњаковић, Ивона Васић/Жибрег, Вера Васић, Јасмина Грковић Mејџор, Гордана Галетин/Драгин, Мирјана Бурзан, Нада Малетић/Арсенијевић, Ивана Антонић, Жељко Марковић, Наташа Драгин, Марина Петровски/Курешевић, Слободан Павловић, Гордана Штасни, Душанка Звекић Душановић, Исидора Ченејац/Бјелаковић, Јелена Војновић/Ајџановић, Миливој Алановић, Наташа Бугарски/Киш, Милан Ајџановић, Дејан Средојевић, Страхиња Степанов, Биљана Бабић, Јелена Редли, Данка Урошевић/Вујаклија, Мила Драгић, Александра Цолић/Јовановић. Потом, они који су радили / раде на другим Катедрама / Институтима / Одсецима, библиотеци или службама на новосадском Филозофском факултету: Меланија Микеш, Племенка Влаховић, Светлана Бранковић, Предраг Пипер, Душанка Мирић, Ксенија Кончаревић, Ивана Живанчевић Секеруш, Ненад Крстић, Марина Фратуцан, Дејан Пралица, Соња Филиповић, Биљана Радић Бојанић, Ана Халас, Љиљана Матић,

\footnotetext{
${ }^{2}$ Имена наводим по редоследу појављивања на страницама часописа.
} 
Милица Брацић, Ивана Симовљевић, и они који су у Матици српској радили / раде на научно-истраживачким пројектима и речницима: Милица Бујас, Ксенија Минчић, Душица Грбић, Светлана Ђурагић/Вареника, Дејан Милорадов, Ивана Црњак. Затим они коју су радили или и данас раде на пројектима Института за српски језик САНУ: Татјана Батистић, Драго Ћупић, Светозар Стијовић, Слободан Реметић, Станимир Ракић, Софија Ракић Милојковић/Милорадовић, Милош Луковић, Ивана Коњик, Зоран Симић, Бранкица Марковић, Драгана Радовановић, Миљана Чопа и они који су радили или и данас раде на другим факултетима / институтима у Србији или региону: Јосип Баотић (Нови Сад/Сарајево), Душан Јовић (Нови Сад/Београд), Првослав Радић (Београд), Јасна Мелвингер (Нови Сад/Осијек), Бранко Тошовић (Сарајево/Грац), Биљана Савић и Дијана Савић (Нови Сад/Бањалука), Јасмина Вучић (Нови Сад/Косовска Митровица), Весна Пожгај Хаџи и Ива Фербежар (Љубљана). Па они који су везани за друге институције, гимназије и школе, медије: штампу, радио и ТВ, позориште: Самуел Болдоцки, Мирко Чанадановић, Бранислава Ром, Јарослав Турчан, Драгица Бећар, Гордана Станековић, Марија Грасл, Мара Агић, Славица Шокица, Марија Шпис, Милена Ђурђић, Вера Бадрљица/Малетић, Марија Тир, Жанко Томић, Вишња Кризманић, Константин Кнежевић, Маја Седларевић, Милена Зорић, Милица Ружичић. Они који су касније у иностранству били лектори за српски језик као страни: Милица Лађевић, Мирко Радојчић, Данко Шипка, и коначно страни аутори: Александар Албин (САД), Светлана Зајцева (Русија), Ласло Деже (Мађарска), Т.А. Иванова (Русија), Кита Бицевска (Македонија), Алина Маслова (Русија), Ева Калишевска (Пољска), Ана Петрикова Климчукова (Словачка), Ирина Песоцкаја (Русија), Ана Верчик, Талин Естонија, Џим Хлавач (Аустралија), Наталија Јурјевна Плаксина (Русија), Панајотис Асимопулос (Грчка). Напокон, међу ауторима прилога је још читав низ некадашњих студената, основних и последипломских, а данас дипломских (мастер) и докторских студија. Имена је пуно и, разумљиво, не могу овом приликом сва бити поменута, а уколико је неко име изостало по наведеним групама, једини разлог је недостатак информације. Највише прилога имао је Стеван Ђапић, 17, претежно из микротопонимије Баната, а затим Милица Грковић, Јасмина Грковић Мејџор, Момчило Златановић и Жарко Бошњаковић, по осам. 
Закључно са бројем 39 (2008), до када су се наводила имена професора под чијим руководством је рад урађен, појављују се имена 26 професора са Одсека за српски језик и лингвистику, један са Одсека за англистику и 9 са других факултета у земљи и иностранству, укупно, дакле, њих 36. Пре свих свакако: професори Петар Ђорђић (1) ${ }^{3}$, Павле Ивић (51), Милка Ивић (27), Рудолф Коларич (13), Александар Младеновић (31) и Јован Кашић (13). А њих чак 20-оро били су и аутори својих првих радова у часопису Прилози проучавағу језика, а касније су руководили радовима својих студената: Велимир Михајловић (7), Драгољуб Петровић (34), Милорад Радовановић (9), Вера Јерковић (12), Свенка Савић (17), Милица Грковић (2), Мато Пижурица (5), Мирјана Бурзан (2), Љиљана Суботић (15), Јован Јерковић (2), Владислава Петровић/Ружић (19), Гордана Вуковић (6), Мирјана Јоцић (3), Јасмина Грковић Мејџор (12), Вера Васић (19), Љиљана Недељков (6), Ивана Антонић (4), Слободан Павловић (1), Нада Арсенијевић (1), Љиљана Петровачки (2). Међу менторима радова са других Одсека новосадског Филозофског факултета био је и професор Твртко Прћић (7) са Одсека за англистику, а са других факултета из земље и иностранства, то су били и П. Дмитријева, Мила Стојнић, Малик Мухић, Н.И. Толстој, Ксенија Милошевић, Радмила Угринова Сколоска, Даринка Гортан Премк, Данко Шипка, Н.Б. Лебедева (свако по један рад). Такође, закључно с бројем 39 (2008), објављено је и 62 рада без имена ментора. Од броја 40 (2009) до броја 49 (2018) међу менторима које су аутори именовали у напомени нашли су се са претходног списка Јасмина Грковић Мејџор (5), Вера Васић (1), Љиљана Недељков (1), Ивана Антонић (1), Слободан Павловић (4) и Љиљана Петровачки (1), као и: Гордана Штрбац, Марина Курешевић, Јасмина Дражић, Душанка Звекић Душановић, те са других факултета: Слободан Реметић, Рајна Драгићевић и Катарина Расулић. Ипак, у последњих девет бројева највећи број аутора, њих 59, није у напомени навело име професора под чијим руководством је рад урађен. Неупоредиво највећим бројем радова руководио је професор Павле Ивић. Био је руководилац 50 радова, и то у периоду између 1965. и 1975, а након те године његово име стајаће још само

\footnotetext{
${ }^{3}$ Имена наводим према редоследу појављивања на страницама часописа, а број у загради представља број радова којима је професор руководио.
} 
испод наслова једнога рада, 1984. године. Иза њега следе професори Драгољуб Петровић (34), Александар Младеновић (31) и Милка Ивић (27).

Језичке теме које су обрађиване у часопису Прилози проучавању језика припадале су различитим лингвистичким областима. Без улажења у детаље, свакако највећи број тема припадао је историји језика, и то приближно подједнако српскословенском периоду и периоду 18. и 19. века, при том предмет пажње су биле у већини случајева фонолошке и морфолошке језичке црте, а тек у новије време и синтаксичке. Потом дијалектологији, при чему је дијалекатска лексика била најчешћи предмет анализе, и синтакси савременог стандардног српскохрватског / српског језика. Велики број радова, нарочито до пред крај 80-их година, бавио се ономастиком, антропонимијом, патронимијом, топономијом и микротопонимијом. Следе по учесталости радови који су се бавили различитим сегментима лексикологије: лексичком семантиком, терминологијом и фразеологијом. Потом интердисциплинарне теме из: анализе дискурса и језика медија, прагматике, социолингвистике и психолингвистике, посебно из проблематике усвајања и развоја језика. Било је и радова који су се бавили фонологијом, морфологијом и дериватологијом савременог стандарда, језичком интерференцијом српског и мађарског као језицима у непосредном контакту и унутрашњим језичким грешкама у процесу учења српског као страног, те језичким контрастирањем српског и енглеског, руског, пољског, француског језика.

Једно од најважнијих програмских начела које је оснивачка редакција часописа Прилози проучавању језика истакла на самом почетку, и којег су се и све касније редакције доследно придржавале, било је да прилози младих сарадника који се објављују у часопису морају бити засновани на анализи аутентичне језичке грађе било да је она прикупљана на дијалекатском терену, у библиотеци међу архивском историјско-језичком грађом или из различитих писаних или говорних извора функционално обележених за савремени стандардни српски језик. У том смислу убедљива већина радова објављених у Прилозима проучавању језика почевши од првог броја припада категорији 'изворни научни рад', а само по изузетку штампани су радови у којима се даје преглед постојеће литературе о одређеном језичком проблему и који припадају категорији 'прегледни чланак'. То другим речима значи да је безмало сваки објављени рад пружао увид у нову језичку грађу и у том смислу нудио и језички материјал за даља истраживања истог или неког 
другог језичког проблема. Један део презентоване и у овим радовима анализиране језичке грађе касније је интегрисан или је послужио као корисна основа за монографске студије, речнике и граматике. Али уз то, многи радови су поред аналитичког дела имали на крају и додатак у којем је била изложена и систематизована целокупна прикупљена грађа коришћена за анализу. Такве додатке су по правилу имали сви радови који су се бавили дијалекатском лексиком, ономастиком, антропонимијом, патронимијом, топонимијом, микротопонимијом, терминологијама, али и радови који су се бавили синтаксичким понашањем појединих семантичких класа глагола у старијем или савременом језику, када су прилагани мали синтаксички речници. Укупно 68 радова има приложену грађу у виду тезауруса или речника. Посебно дијалектолошки радови нудили су језичку грађу у виду акцентованих текстова, односно танскрипата језичке грађе снимљене на терену и обрађене и припремљене за различите језичке анализе. Сва грађа прикупљена на терену и презентована у форми тезауруса, речника или текстуалних транкрипата и данас представља драгоцени извор језичке грађе за лингвистичка, али етнолингвистичка па и културолошка истраживања.

Сви радови су, без изузетка, имали и референтну литературу. Ако би се саставила укупна библиографија, или библиографија по појединим областима, литературе на коју су у својим радовима упућивали аутори добили бисмо позамашну библиографију релевантне филолошке и лингвистичке литературе која би, с једне стране, сведочила о темељном школовању и правилном усмеравању аутора прилога, а с друге стране умногоме би говорила и о актуалности истраживачких тема које су аутори и њихови ментори бирали у појединим периодима посматрано у ширем лингвистичком контексту. У Прилозима су објављене и три посебне тематске библиографије. У броју 2 (1966) Прилог библиографији о творби речи у српскохрватском језику, коју је урадила Јања Шакић под руководством Павла Ивића, која садржи 139 библиографских јединица и представља једну од ретких коментарисаних тематских библиографија у нашој лингвистици. У броју 5 (1969) уз рад Свенке Савић Синтаксичке конструкиије с придевима у српскохрватском књижевном језику, рађен под руководством Милке Ивић, дат је Прилог библиографији радова о придевима у српскохрватском језику који садржи 93 библиографске јединице. У броју 20 (1984) Ивона Жибрег, под руководством Милорада Радовановића, објавила је Bibliografiju radova o 
presupozicijama u јeziku која садржи 669 махом иностраних библиографских јединица.

Поједини бројеви часописа Прилози проучавању језика, поред редовних прилога младих истраживача, имали су и неке ванредне чији су аутори били асистенти, доценти или професори Катедре/Института/Одсека.

Број 1 (1965), осим већ поменутог уводног текста редакције под насловом Поводом овог почетка, на самом крају садржи и Извештај о научноистраживачком раду упућен Катедри за јужнословенске језике који су поднели др Александар Младеновић и Јован Кашић. Из њега сазнајемо да је Александар Младеновић током лета 1964. боравио у архивима у Задру, Котору и Цетињу проучавајући „графију наших старих ћирилских споменика насталих на западу српскохрватске језичке територије ... и језик наших старих докумената, нарочито са терена Боке Которске и Црне Горе”, а Јован Кашић је, такође у лето 1964, радио на прикупљању материјала за дисертацију о језику Милована Видаковића, и у ту сврху трагао за утицајем дијалектске базе на његов језик, те бележио и снимао говор Ирига, где је Видаковић одрастао, али и утицај бачких говора, посебно говора Новог Сада, где је Видаковић дуже боравио, и с тим циљем у Институту за српскохрватски језик детаљно прегледао опширан рад Ивана Поповића посвећен говору Новог Сада.

У броју 4 (1968) Јован Кашић извештава о Лингвистичким вечерима на Филозофском факултету у Новом Саду. Наиме, током 1968. године одржавани су редовни месечни лингвистички састанци чији је циљ био двојак: „да се присутни упознају, у првом реду, са резултатима оригиналних проучавања лингвиста који делују у Новом Саду, а затим, на основу посебних реферата о објављеним делима, и са резултатима до којих су дошли језички стручњаци у другим срединама“. Из извештаја сазнајемо да је први састанак одржан 7. јануара 1968. и да је током те године одржано укупно десет састанака, а да је поред предавача из Новог Сада: Рудолфа Коларича, Милке и Павла Ивића, Меланије Микеш, Племенке Влаховић и Александра Младеновића, било и иностраних предавача: Einar Haugen (Универзитет Харвард, САД), William D. Sweeeney (тада лектор на новосадској Катедри за енглески језик), Ferenc Kiefer (Мађарска), William Shipley (Универзитет у Санта Крузу, у Калифорнији); о лингвистичким истраживањима у другим срединама и новим књигама и речницима реферате 
су поднели: Јасна Мелвигер, Велимир Михајловић, Лидија Дмитријев, Љиљана Бибовић и Јован Кашић.

У броју 7 (1971) Велимир Михајловић пише $O$ једном пројекту Института за лингвистику: грађа за речник страних речи у предвуковском nериоду. Детаљно образлаже потребу за покретање рада на пројекту који би у центар истраживачке пажње ставио период у развоју српског језика који је у тада актуелним пројектима остао непокривен, а до тада недовољно истражен, а посебно страну лексику која у предвуковском периоду, нарочито на терену Војводине, пристиже под утицајем интензивног укључивања српске културе у европске токове.

У броју 19 (1983) Милорад Радовановић пише Хронику Института за јужнословенске језике, а у броју 23 (1987) Ивона Жибрег објављује Хронику Института за јужнословенске језике II. Обе хронике, почевши од 1979. закључно са фебруаром 1987, бележиле су хронологију догађаја који су се одвијали у тада Институту за јужнословенске језике: предавања наставника из Института и предавања гостујућих професора са других факултета у земљи и иностранству, која су одржавана као део ваннаставних активности Инстутута, као и она која су била део тадашњег програма предмета Савремена лингвистичка теорија и пракса на постдипломским студијама, а које су одржаване школске 1981/82. и 1982/83; потом промоције књига наставника и сарадника Института које су се редовно одржавале, научне конференције чији је организатор био Институт, Свечане седнице Института уприличене посебним поводима, предавања и лекторска вежбања у оквиру Скупа слависта која су се у организацији Међународног славистичког центра одржавала и у Новом Саду или Југословенског семинара за стране слависте, који се, поред Задра, једним делом одвијао и у Новом Саду. Ове две хронике забележиле су током само осам година, колико су помно вођене, 158 предавања, промоција књига, научних скупова. Број лингвиста, домаћих и иностраних који су држали предавање или реферат у Новом Саду илузорно је бројати. Поменућу само нека имена, и данас шире позната, на која се наилази у овим хроникама. Од иностраних предавача: Z. Topolińska (Пољска), J.A. Fishman (САД), П. Чучка (Ужгород, СССР), К.E. Naylor (САД), М. Сурдучки (Канада), W. Browne (SAD), A. Martinet (Француска), T. Slama-Casacu (Румунија), P. Sgall i J. Panevová (Чехословачка), Лили Лашкова (Бугарска), H.K. Mikkelsen i T. Skutnabb-Kangas (Данска); од предавача са других овдашњих факултета и института: Смиљка Васић, 
Митар Пешикан, Гордана Јовановић, Ранко Бугарски, Живојин Станојчић, Милорад Дешић, Љубомир Поповић, Иван Клајн (Београд), Adrijana Wolf, Милан Могуш, Дубравко Шкиљан (Загреб), Дуња Јутронић-Тихомировић (Задар), Милош Окука (Сарајево), а од предавача који су били са других Института Филозофског факултета: Сретен Марић, Павица Мразовић, Предраг Пипер. Теме њихових предавања припадале су самом врху по актуелности у лингвистици тога времена, а неке од тих тема и данас су у центру пажње истраживача у лингвистици и славистици. Хроника није вођена пре 1979, нити после 1987, што је велика штета јер би се на овом списку нашла још нека имена вредна пажње, а позната и у међународним оквирима.

У броју 21 (1985) Драгољуб Петровић пише уводни текст Поводом јубилеја Милке Ивић и Павла Ивића. То је текст који је прочитао 15. фебруара 1985. у Матици српској на свечаној промоцији XXVII-XXVIII књиге Зборника Матице српске за филологију и лингвистику који је био посвећен 60. годишњици Милке Ивић и Павла Ивића. „Редакција часописа Прилози проучавању језика, чији су покретачи и дугогодишњи уредници били Ивићеви с поштовањем бележи тај датум,” написао је у напомени уз овај текст професор Петровић, а у самоме тексту и следеће речи: „И били су за то време најбољи учитељи својим ученицима и најмудрији сабеседници својим сабеседницима. Бивали су, и сад бивају, на свим оним скуповима који умеју и хоће да саслушају умну реч и да се у складу са њом понашају, а није их бивало, нити их има, тамо где је она бивала магла и где се не чује ни своја а камоли туђа".

У броју 34 (2003) Љиљана Суботић пише текст Поводом педесете годишњище од оснивања Одсека за српски језик и лингвистику и од уписа педесете [! прве] генераиије студената. Представљен је историјат Катедре/Института/Одсека, као једног од најстаријих на Филозофском факултету, али и на Универзитету у Новом Саду, нужно у кратком прегледу, о педесет година активног рада, педагошког, научно-истраживачког и издавачког, континуираног напредовања и постепеног, понекад, истина, и са застојима, али, ипак, сталног подмлађивања.

И у броју 45 (2014) Гордана Штрбац под наднасловом Хроника пише Приказ резултата научно-истраживачког рада наставника са Одсека за српски језик и лингвистику (2009-2013). Представљене су активности и резултати пре свега у виду публикованих монографских студија проистеклих 
из магистарских радова и докторских дисертација, зборника радова, књига и речника које су наставници и сарадници Одсека урадили на два пројекта: Стандардни српски језик: синтаксичка, семантичка и прагматичка истраживања, којим је у том периоду руководила Владислава Ружић и Историја српског језика чији је руководилац била тада, а и данас је, Јасмина Грковић Мејџор, а које је финансирало, из програма Основних истраживања, Министарство просвете, науке и технолошког развоја Владе Републике Србије. Овај кратки преглед само за период од четири године (2009-2013) сведочи о квантитативно, али и квалитативно вредним научним резултатима који настају на ова два пројекта, а највећим делом их постижу наставници и сарадници Одсека за српски језик и лингвистику. Уколико би се неком згодном пригодом сачинила обједињена библиографија наставника и сарадника Катедре/Института/Одсека настала на пројектима, али ван њих, од оснивања 1954, и стручна, али и шира јавност стекла би прави и потпуни увид у укупни досадашњи домет научне продукције новосадске лингвистичке средине.

Коначно, у два наврата до сада штампана је и Библиографија радова објављених у Прилозима проучавању језика. У броју 20 (1984) тадашња библиотекарка Семинарске библиотеке Института Љиљана Спасић сачинила је библиографију радова по ауторима за бројеве 1-20 (1965-1984), а у броју 45 (2014) Наташа Белић, садашња библиотекарка Семинарске библиотеке Одсека, урадила је библиографију, такође по ауторима, за бројеве 21-44 (1985-2013). Уз обе библиографије приложен је и Именски регистар. За овај, 50. број, Наташа Белић објединила је те две библиографије, технички их уједначила и придодала им библиографске јединице радова објављених у бројевима 45-50 (2014-2019).

Часопис Прилози проучавању језика несумњиво је јединствен филолошколингвистички часопис на јужнословенском простору, у славистичком окружењу, а вероватно и у лингвистичком свету уопште - јединствен по својој мисији: намењен студентима и млађим сарадницима, истраживачима српског језика, филологије и лингвистике, који радовима објављеним у њему стичу своја прва искуства у истраживачком раду и презентовању научних резултата; по дужини трајања: више од пола века опстаје и редовно се публикује па има статус часописа националног значаја; и свакако по укупном досадашњем доприносу: с једне стране релевантним прилозима различитим областима србистике, а с друге стране у стварању и обликовању 
компетентних истраживача и факултетских наставника српског језика и лингвистике. Увидом у досадашњих 49 бројева, као и у овај 50, који сада стоји пред читаоцима, уочава се континуитет, озбиљност и надасве истрајност у настојању да се циљеви које је поставила прва редакција часописа остварују без компромиса. Будућим редакцијама и уредницима, а посебно будућим менторима, остаје велика обавеза да часопис одрже и да достигнути ниво барем задрже, ако не и унапреде (нпр. увођењем рубрике $O$ новим къигама), али свакако да не дозволе да се успостављени критерији снизе зарад краткотрајних и ефемерних постигнућа.

Проф. др Ивана Антонић

Одсек за српски језик и лингвистику Филозофски факултет, Универзитет у Новом Саду

Србија iantonic@ff.uns.ac.rs 